\title{
EU geography of non-performing loans (NPL) 幽
}

\author{
Sergey Avetisyan ${ }^{\mathrm{a}, \mathrm{b}, 1}$ \\ ${ }^{a}$ avetisyan.sergej@gmail.com \\ sergey.avetisyan@cba.am \\ ${ }^{b}$ The Central Bank of Armenia, Economic Research Department \\ Dilijan Research and Training Centre
}

\begin{abstract}
Over the past decade, the credit quality of loan portfolios across most countries in the world remained relatively stable until the financial crises hit the global economy in 2007-2008.

In this paper I discuss, the relationship between non-performing loans and economic landscape. Since 2008, nonperforming loans have been an increasingly hot topic in the international scene, due to their important and rising volume and their impact on the economy as a whole, on the banking system and on its credit supply. Since then, average bank asset quality deteriorated sharply due to the global economic recession. Yet the deterioration of loan performance was very uneven across countries. I am interested in explaining these differences in bank asset quality across countries and over time. In this paper, I therefore study the empirical determinants of non-performing loan (NPL) ratios using a data set for EU countries covering the past decade.

The paper assumes that the spatial organization of banking systems and the geographical distribution of comercial banks branches, ATMs and GDP growth are major factors influencing the effectiveness in credit system. The aim of this paper is to construct a continuous and quantifiable model, which will demonstrate a role of economic condition, technology, competition, policy, business climate in Financial Stability. Main hypotheses suggests, that GDP growth, interest rate, new business, FDI, ATMs and geographical distribution of branches have an influences on NPL (non-performing loans).
\end{abstract}

Keywords: non-performing loans, financial stability, economic geography, bank branches JEL: C23, G21, R120

\section{Introduction}

Over the last decade the structural features of global banking systems have radically altered. Developed banking markets have all experienced significant declines in the number

\footnotetext{
This Paper should not be reported as representing the views of Central Bank of Armenia. The views in this paper are those of the author and should not be interpreted as those of Central Bank of Armenia.

Email address: avetisyan.sergej@gmail.com, sergey.avetisyan@cba.am (Sergey Avetisyan)

${ }^{1}$ Preliminary Draft. Comments Welcome.
} 
of banks and industry concentration has generally increased at both the national and regional levels [4]. The literature on geography of finance has seen a dramatic growth over the last number of decades. For better understanding of relevant theoretical knowledge more tractable, it might be useful to group it into the three key areas of financial stability: the macroeconomy, financial institutions, and financial markets. Several studies have empirically examined how geographic distance is related to banking ([3],[6],[7],[1],[8]).

The theory of financial intermediation earlier developed by Leland and Pyle, and Diamond $([5],[9])$ show ed that if the information required by the financial institutions is not sufficient, several problems could occur. One of the major problems is the increase of the level of bad loans, also called the non-performing loans

According to an IMF Staff Discussion Note published in September 2015, NPL constitute a drag on economic activity, especially for countries that rely mainly on bank financing, as is the case in the euro area. High NPL reduce profitability, increase funding costs and tie up bank capital, which negatively impact credit supply and ultimately growth. Using different country samples, all recent studies find that higher NPLs tend to reduce the credit to GDP ratio and GDP growth, while increasing unemployment. This is consistent with the data for Euro Area banks over the last five years (See notably European Investment Bank, 'Unlocking lending in Europe', October 2014). According to an IMF study (See 'Euro area policies, selected issues: policy options for tackling non-performing loans in the euro area', IMF country report, No 15/205, July 2015), credit growth remains slow in countries where banks report a high level of impaired assets and insolvency procedures are weak. Euro Area banks with higher NPLs ratios in 2012-2013 have been lending less than banks with average asset quality operating in the same country under the same demand conditions.

It is rare to find an economics text in which space is studied as an important subject. As argued Krugman [14], this is probably because economists lacked a model embracing both increasing returns and imperfect competition, the two basic ingredients of the formation of the economic landscape, as shown by the pioneering work of Hotelling [12], Losch[17], Isard[13].

According to Gallup, Sachs, and Mellinger [10], location and climate have large effects on income levels and income growth, through their effects on transport costs, disease burdens, and agricultural productivity, among other channels. Furthermore, geography seems to be a factor in the choice of economic policy itself.

Our paper is focused around the one principal question: analysis of non-performing loans in EU countries.

New economic geography support a lot of methods for time-space-structural analysis ([18], [19], [21]). The bulk of geographical writing about finance and money consists of sectoral contributions. These take a comparatively narrow segment and penetrate it at varying depth. Most writing is of article length which sets its restrictions. The field at large has become popular only since the late 1980s [15].

Macroeconomic conditions will play a key role in setting the NPL strategy and are best incorporated in a dynamic manner. This also includes the dynamics of the real estate market and its specific relevant sub-segments. For banks with specific sector concentrations in their NPL portfolios (e.g. shipping or agriculture), a thorough and constant analysis of the sector 
dynamics should be performed, to inform the NPL strategy. A reduction of the risk stemming from NPLs can be achieved and should be the aim, even in less favourable macroeconomic conditions.

This literature review will examine essential characteristics of space and financial stability. Some research has identified a difference between "bank-based" and "market-based" financial system ([22], [16]), argue that geography is the important in the evolution of money and there has been a failure to be suitably sensitive to the interplay between money, space and place, to see that monetary forms, practices and institutions are contingent in both space and time, and that money has often evolved in order to solve more general problems of time-space co-ordination. Generally money allows social relationships and must be extended across space and time.

\subsection{NPLs are a legacy of the crisis}

What has been done so far to tackle them? Over the past years, the Commission has been working constructively with the concerned Member States to reduce banks' NPLs, including through the European Semester. Some Member States have already made great strides in cleaning up bank balance sheets since the crisis. It is important to build-up on these efforts, consolidate the trend and prevent the build-up of new NPLs, with a comprehensive set of actions agreed at the ECOFIN that both European institutions and Member States must work on.

\subsection{Logic}

Which factor are important for financial stability? Credit quality is an important issue in financial systems and in the real economy. Macroeconomic stability, competition issues and regulatory supervision all affect and are affected by banks' credit quality.

Economic models have not been primarily concerned with the question of spatial distribution of economic activity, since they often implicitly assume that markets ensure a geographically well-distributed economy.

Allen and Wood (2006) define a financially stable system as simply one: "which is not prone to episodes of financial instability" [2]. NPL one of the variables financial stability.

There is no single definition of a non-performing loan. Country definitions differ, and it is recognized that it is possible that what is appropriate in one country may not be so in another.

Our main idea is a to demonstrate factors which are important for financial stability mainly on NPL.

$$
N P L=\underbrace{F D I}_{\text {economiccondition }}+\underbrace{A T M}_{\text {technology }}+\underbrace{B R A N C H}_{\text {competition }}+\underbrace{I N T R A T E}_{\text {policy }}+\underbrace{\text { NBUSINESS }}_{\text {businessclimate }}
$$




\subsection{Notes on EU NPLs}

In January 2018 the European Commission presented its first progress report on the Action Plan to tackle non-performing loans (NPLs) in Europe, which Finance Ministers agreed on in July 2017. The progress report ${ }^{2}$, which takes the form of a communication and an accompanying staff working document, highlights recent developments of NPLs both in the EU as a whole and within individual EU countries. It shows that the positive trend of falling NPL ratios and growing coverage ratios has solidified and continued into the second half of 2017. The report also provides an update on the Commission's ongoing work to deliver on the elements of the action plan for which it has direct responsibility. What does latest progress report show? THe data presented int the progress report shows that risk reduction is taking hold in the European banking system: in nearly all Member States, NPL ratios have been falling in recent years. This has been the result of stabilizing economies in concert with various pro-active measures, including sales of NPL portfolios.

How can Eurostat accounting rules shape policy responses to financial crises?

When the recent crisis began, the ESA did not provide clear guidance on how to classify a number of new policies used to respond to the crisis. Eurostat needed to develop new procedures for assessing how these policies would affect member state budgets. The initial result of this effort was a 15 July 2009 decision on "The statistical recording of public interventions to support financial institutions and financial markets during the financial crisis'1, followed on 10 September 2009 by a more detailed statistical guidance note2. See Box 1 for details. Together these documents clarify how certain policies affect debts and deficits under the more general ESA 1995 rules. The 2009 documents dealt specifically with bank recapitalisations, liquidity support, guarantees, direct government asset purchases and exchanges, as well as support to "certain new bodies", such as asset management companies [11].

The rules made distinctions between what policies, and implementations of these policies, counted as "financial transactions" and "contingent liabilities". Financial transactions, such as exchanging cash for an equivalently valued asset, do not count as immediate expenditure because the value of the assets held by the government have not changed. Recapitalisations would count as financial transactions if the bank had not suffered a loss over more than one accounting period and the purchase was not an exceptional one-off transaction in the context of a crisis. Contingent liabilities are liabilities that governments incur - such as guarantees to, and ownership stakes in, certain types of AMCs - but which are not treated as immediately impacting the public debt. Contingent liabilities only count against the debt when some event happens, such as a guaranteed bond not being paid back by the issuer.

\section{Data and methodological notes}

\subsection{Descriptive statistics}

To the best of our knowledge, this is one of the few studies that examines factors affecting NPL in EU by means of ATM, BRANCHES, NBUINESS, FDI and INTRATE data (about

\footnotetext{
${ }^{2}$ Communication From The Commission To The European Parliament, The Council And The European Central Bank ( First Progress Report on the Reduction of Non-Performing Loans in Europe)
} 
Table 1: Descriptive statistics

\begin{tabular}{llllll} 
Variable & Obs & Mean & Std. Dev. & Min & Max \\
\hline \hline NPL & 246 & 8.005391 & 8.088509 & .1455885 & 48.67586 \\
ATM & 252 & 4.522106 & 1.000825 & 0 & 5.525453 \\
BRANCHES & 252 & 4.50018 & 1.03857 & 0 & 5.521461 \\
NBUINESS & 196 & 3.104017 & 1.889547 & 0 & 5.010635 \\
FDI & 252 & 4.544048 & .9611125 & 0 & 5.529429 \\
GDP & 252 & .8374733 & 3.811191 & -14.81416 & 25.55729 \\
INTRATE & 252 & 18.53968 & 27.88498 & 1 & 88
\end{tabular}

Table 2: Non-performing loans and provisions by Member State

Source: ECB, Consolidated Banking Data. Calculations by Commission services (DG FISMA)

definitions and data sources see Table.5).

I start this section analyzing the descriptive statistics of the different variables. The descriptive statistics of the variables used in this empirical analysis are presented in Table 1. I also illustrate maps (Figures 2-5) for chosen variables. The descriptive statistics show that the mean of non-performing loans in EU countries is about $8 \%$ (Table1).

\section{2. $N P L$}

Definition of non-performing loan in Financial Times Lexicon: A loan on which the borrower is not making interest payments or repaying any principal. At what point the loan is classified as non-performing by the bank, and when it becomes bad debt, depends on local regulations. Banks normally set aside money to cover potential losses on loans (loan loss provisions) and write off bad debt in their profit and loss account. In some countries, banks that have accumulated too many NPLs are able to sell them on - at a discount - to specially established asset management companies (AMCs), which attempt to recover at least some of the money owed.

\subsection{FDI}

Both EU inward flows (direct investments in EU Member States from non-member countries) and outward flows (EU Member States' direct investments in countries outside the EU) fell sharply in 2014 and were at their lowest levels during the period 2009-2015. These big falls were mainly due to large disinvestments in the traditional partner countries - the United States and Switzerland - as well as disinvestments from the United States in the EU. In 2015, the level of inward and outward FDI flows returned to a similar level to that recorded in 2013.

\subsection{Branches and ATMs}

According to Serna (2005) "bank branches are the primary place in which consumers have access to products for either building assets and obtaining credit" [20]. 


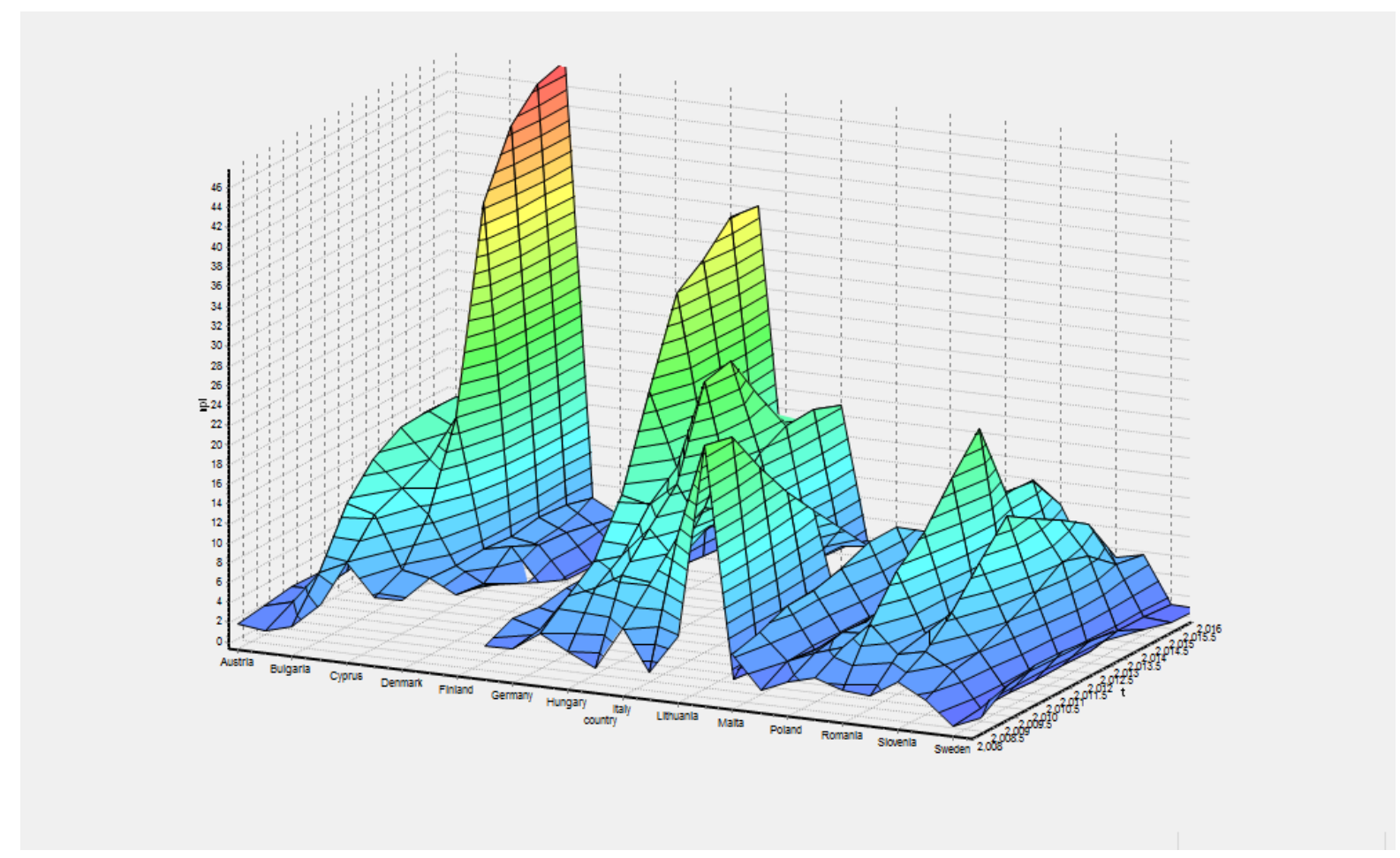

Figure 1: NPLs in EU 2008-2016.

Latest tendency to adopt multichannel banking strategies has been increasing, it seems evident that the traditional bank branch network still has a relevant role in the banking activity.

The fact that there are multiple intangible variables influencing branch attractiveness and profitability complicates the identification and development of evaluation systems. Many of the intangible variables are outside the banks' sphere of control, and this increases the interest (but also the difficulty) of developing potential attractiveness measurement frameworks.

Bank branches will continue to be a primary point of service, it seems evident that relative bank success will depend on the use of evaluation systems to measure bank branch performance and attractiveness. Location selection is one of the most important decision making process which requires to consider several criteria based on the mission and the strategy.

\section{Concluding remarks}

In the present study, we applied an econometric model that helped us to identify factors that influence the rate of non-performing loans in the EU28, focused on post-crisis period. Using aggregate data (Figure 1) on a panel of 28 countries for the period 2008- 2016 and applying the difference GMM estimation, we found strong correlations (Table 3) between NPL and various factors.

Taking into consideration that the basic aim of our study is to investigate the factors 
Table 3: Correlation matrix

\begin{tabular}{llllllll}
\hline & GDP & NPL & FDI & ATM & BRANCH & INTRATE & NBUSIN S \\
\hline GDP & 1 & & & & & & \\
& & & & & & & \\
NPL & -0.0555 & 1 & & & & & \\
FDI & 0.0723 & 0.1037 & 1 & & & & \\
ATM & -0.0005 & 0.0933 & -0.166 & 1 & & 1 \\
BRANCH & -0.1429 & 0.1838 & -0.0152 & 0.0663 & 1 & \\
INTRATE & -0.0587 & 0.0178 & -0.1691 & 0.3612 & -0.0517 & 1 \\
NBUSINESS & -0.1828 & 0.0242 & 0.0496 & -0.1183 & 0.0451 & 0.0568 & 1 \\
\hline
\end{tabular}

Table 4: Dynamic panel-data estimation, two-step difference GMM

\begin{tabular}{lll} 
NPL & Coef. & $\mathrm{P}>\mathrm{t}$ \\
\hline \hline ATM & -.5073404 & 0.609 \\
BRANCHES & -4.901884 & 0.692 \\
NBUINESS & -.5561134 & 0.232 \\
FDI & -.5779522 & 0.659 \\
INTRATE & .1088831 & 0.664 \\
\hline AR(1) & 0.582 & \\
AR(2) & 0.868 & \\
Hansen test of overid. restrictions: & 0.345 & \\
Hansen test excluding group: & 0.118 Difference & 0.507 \\
Hansen test excluding group: & 0.210 Difference & 0.345
\end{tabular}




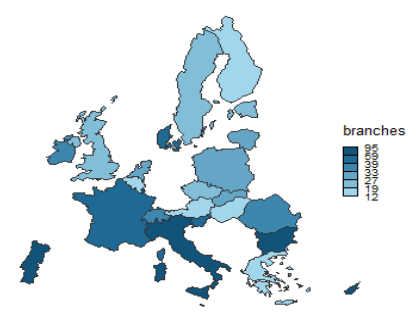

(a) 2008

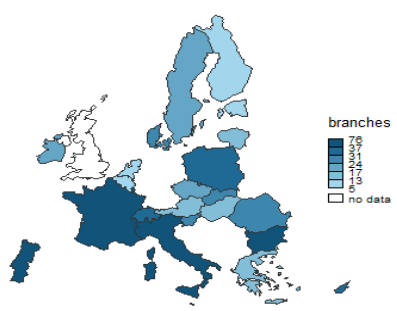

(b) 2016

Figure 2: Branches (per 100,000 adults)

Source: authors' own elaborations on data from the //data.worldbank.org

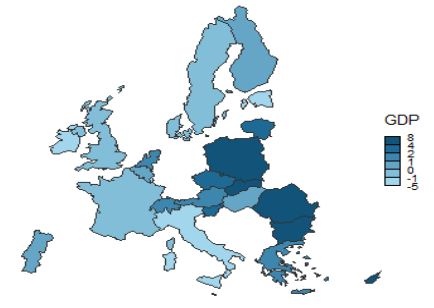

(a) 2008

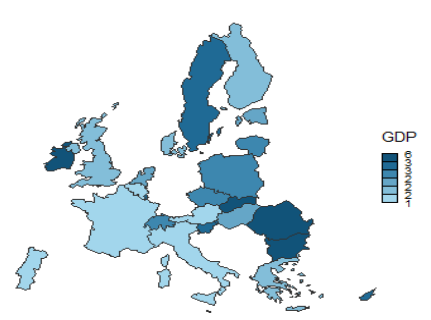

(b) 2016

Figure 3: GDP

Source: authors' own elaborations on data from the //data.worldbank.org

that influence non-performing loans, the estimation results of our difference GMM models were quite interesting. All findings are reported in Table 4. The model suggests that ATM, BRANCHES, NBUINESS and FDI associated with NPL are negatively. For planners it means that the focus on the availability and quality of local services could bring important impulses for growth. The Dynamic GMM show coefficient between INTRATE and NPL is positive.

Our analysis could be of interest to policy makers for two main reasons. First, the assessment of overall asset quality and credit risk in the financial sector is an important element of macro-prudential surveillance. A thorough understanding of its drivers facilitates the identification of key vulnerabilities of the financial sector.

Second, regular stress tests of loan quality are increasingly based on macroeconomic assumptions in order to provide common scenarios for all financial institutions participating in such an exercise. Stress tests of loan quality were also an important element of recently conducted stress tests with the aim of restoring confidence in financial systems. Finally, our results can serve as a cross-check for bank supervisors in emerging markets who wish to set 


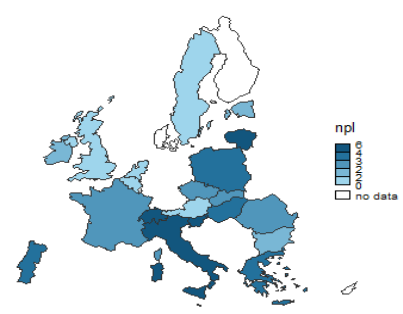

(a) 2008

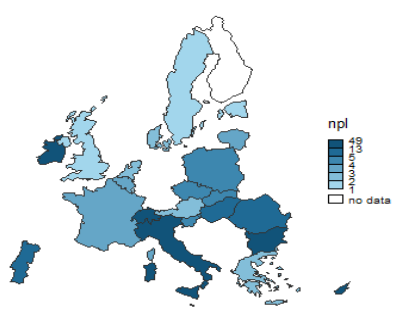

(b) 2016

Figure 4: Bank nonperforming loans to total gross loans (\%)

Source: authors' own elaborations on data from the //data.worldbank.org

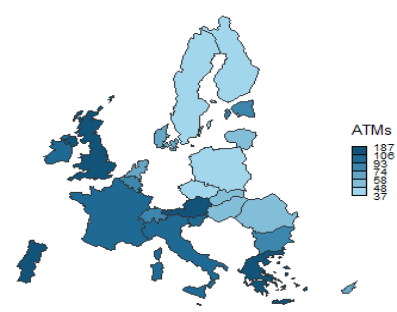

(a) 2008

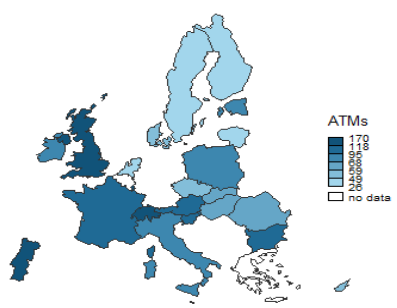

(b) 2016

Figure 5: ATMs (per 100,000 adults)

Source: authors' own elaborations on data from the //data.worldbank.org

up econometric models linking NPLs with macroeconomic indicators. For the calibration of stress tests in the major economies with more sophisticated financial systems though, higher quality NPL figures (at higher frequencies and disaggregated by sector) may be available and allow more precise country-specific estimates. In response, banks should: develop action plans to be prepared for discussion with their supervisory team and the next Supervisory Review and Evaluation Process cycle.

The results show that the chosen variables can be important factors for understanding non-performing loan in EU.

\section{References}

[1] Pietro Alessandrini, Andrea F Presbitero, and Alberto Zazzaro. "Banks, distances and firms' financing constraints". In: Review of Finance 13.2 (2009), pp. 261-307.

[2] William A Allen and Geoffrey Wood. "Defining and achieving financial stability". In: Journal of Financial Stability 2.2 (2006), pp. 152-172. 
[3] Andrea Bellucci, Alexander Borisov, and Alberto Zazzaro. "Do banks price discriminate spatially? Evidence from small business lending in local credit markets". In: Journal of Banking E Finance 37.11 (2013), pp. 4183-4197.

[4] Allen N Berger, Philip Molyneux, and John OS Wilson. The Oxford handbook of banking. OUP Oxford, 2014.

[5] Richard Brealey, Hayne E Leland, and David H Pyle. "Informational asymmetries, financial structure, and financial intermediation". In: The journal of Finance 32.2 (1977), pp. 371-387.

[6] Kenneth P Brevoort and John D Wolken. "Does distance matter in banking?" In: The Changing Geography of Banking and Finance. Springer, 2009, pp. 27-56.

[7] Geraldo Cerqueiro, Hans Degryse, and Steven Ongena. "Distance, bank organizational structure, and lending decisions". In: The Changing Geography of Banking and Finance. Springer, 2009, pp. 57-74.

[8] Guido De Blasio, Massimo Omiccioli, Luigi Federico Signorini, et al. "Measuring the district effect". In: Chapters (2009).

[9] Douglas W Diamond. "Financial intermediation and delegated monitoring". In: The review of economic studies 51.3 (1984), pp. 393-414.

[10] John Luke Gallup, Jeffrey D Sachs, and Andrew D Mellinger. "Geography and economic development". In: International regional science review 22.2 (1999), pp. 179-232.

[11] Christopher Gandrud and Mark Hallerberg. Bad banks in the EU: The impact of Eurostat rules. Tech. rep. Bruegel Working Paper, 2014.

[12] Harold Hotelling. "Stability in competition". In: The Collected Economics Articles of Harold Hotelling. Springer, 1929, pp. 50-63.

[13] Walter Isard. "Location and space-economy". In: (1956).

[14] Paul R Krugman. Development, geography, and economic theory. Vol. 6. MIT press, 1997.

[15] Risto Laulajainen. Financial geography: a banker's view. Routledge, 2005.

[16] Andrew Leyshon and Nigel Thrift. "Money/Space: geographies of monetary transformation". In: Capital $\&$ Class 22.2 (1998), pp. 182-185.

[17] August Lösch. "The Economics of Location, 1954". In: New Haven, Yale (1940).

[18] Timo Mitze. Empirical Modelling in Regional Science: Towards a Global Time-Space-Structural Analysis. Vol. 657. Springer Science \& Business Media, 2012.

[19] Stefan Nickel, Justo Puerto, and Antonio M Rodrıguez-Chı. "MCDM location problems". In: Multiple criteria decision analysis: State of the art surveys. Springer, 2005, pp. 761-787.

[20] R Serna. "Where are the bank branches in my community? An analysis of branch distribution in low-income neighborhoods". In: California Reinvestment Coalition Report (2005).

[21] Alan Wilson. The science of cities and regions: lectures on mathematical model design. Springer Science \& Business Media, 2012.

[22] John Zysman. Governments, markets, and growth: financial systems and the politics of industrial change. Vol. 15. Cornell University Press, 1984. 
Table .5: Source

\begin{tabular}{|c|c|c|}
\hline Variables & Long definition & Source \\
\hline $\begin{array}{l}\text { Bank nonperforming } \\
\text { loans to total gross } \\
\text { loans }(\%)\end{array}$ & $\begin{array}{l}\text { Bank nonperforming loans to total gross loans are the value of nonperforming } \\
\text { loans divided by the total value of the loan portfolio (including nonperform- } \\
\text { ing loans before the deduction of specific loan-loss provisions). The loan } \\
\text { amount recorded as nonperforming should be the gross value of the loan as } \\
\text { recorded on the balance sheet, not just the amount that is overdue. }\end{array}$ & $\begin{array}{ll}\text { International Monetary } \\
\text { Fund, Global Financial } \\
\text { Stability Report. }\end{array}$ \\
\hline $\begin{array}{l}\text { GDP growth (annual } \\
\%)\end{array}$ & $\begin{array}{l}\text { Annual percentage growth rate of GDP at market prices based on constant } \\
\text { local currency. Aggregates are based on constant } 2010 \text { U.S. dollars. GDP } \\
\text { is the sum of gross value added by all resident producers in the economy } \\
\text { plus any product taxes and minus any subsidies not included in the value of } \\
\text { the products. It is calculated without making deductions for depreciation of } \\
\text { fabricated assets or for depletion and degradation of natural resources. }\end{array}$ & $\begin{array}{l}\text { World Bank national ac- } \\
\text { counts data, and OECD } \\
\text { National Accounts data } \\
\text { files. }\end{array}$ \\
\hline Real interest rate (\%) & $\begin{array}{l}\text { Real interest rate is the lending interest rate adjusted for inflation as mea- } \\
\text { sured by the GDP deflator. The terms and conditions attached to lending } \\
\text { rates differ by country, however, limiting their comparability. }\end{array}$ & $\begin{array}{l}\text { International Monetary } \\
\text { Fund, International Finan- } \\
\text { cial Statistics and data } \\
\text { files using World Bank } \\
\text { data on the GDP deflator. }\end{array}$ \\
\hline $\begin{array}{l}\text { Foreign direct invest- } \\
\text { ment }\end{array}$ & $\begin{array}{l}\text { Foreign direct investment refers to direct investment equity flows in the re- } \\
\text { porting economy. It is the sum of equity capital, reinvestment of earnings, } \\
\text { and other capital. Direct investment is a category of cross-border investment } \\
\text { associated with a resident in one economy having control or a significant de- } \\
\text { gree of influence on the management of an enterprise that is resident in } \\
\text { another economy. Ownership of } 10 \text { percent or more of the ordinary shares of } \\
\text { voting stock is the criterion for determining the existence of a direct invest- } \\
\text { ment relationship. Data are in current U.S. dollars. }\end{array}$ & $\begin{array}{l}\text { International Mone- } \\
\text { tary Fund, Balance } \\
\text { of Payments database, } \\
\text { supplemented by data } \\
\text { from the United Nations } \\
\text { Conference on Trade and } \\
\text { Development and official } \\
\text { national sources. }\end{array}$ \\
\hline $\begin{array}{l}\text { New businesses regis- } \\
\text { tered (number) }\end{array}$ & $\begin{array}{l}\text { New businesses registered are the number of new limited liability corpora- } \\
\text { tions registered in the calendar year. }\end{array}$ & $\begin{array}{l}\text { World Bank's En- } \\
\text { trepreneurship Survey and } \\
\text { database (http://econ. } \\
\text { worldbank.org/research/ } \\
\text { entrepreneurship). }\end{array}$ \\
\hline $\begin{array}{l}\text { Branches } \quad \text { (per } \\
100,000 \text { adults })\end{array}$ & $\begin{array}{l}\text { Commercial bank branches are retail locations of resident commercial banks } \\
\text { and other resident banks that function as commercial banks that provide } \\
\text { financial services to customers and are physically separated from the main } \\
\text { office but not organized as legally separated subsidiaries. }\end{array}$ & $\begin{array}{l}\text { International Monetary } \\
\text { Fund, Financial Access } \\
\text { Survey. }\end{array}$ \\
\hline $\begin{array}{l}\text { (ATMs) (per } 100,000 \\
\text { adults) }\end{array}$ & $\begin{array}{l}\text { Automated teller machines are computerized telecommunications devices } \\
\text { that provide clients of a financial institution with access to financial transac- } \\
\text { tions in a public place. }\end{array}$ & $\begin{array}{l}\text { International Monetary } \\
\text { Fund, Financial Access } \\
\text { Survey. }\end{array}$ \\
\hline
\end{tabular}

